\title{
A Comparative Architectural Study of the Structural Form between Two Religious Buildings in Brasília: The Cathedral and the Tibetan Stupa
}

\author{
Cláudia Estrela Porto \\ Faculty of Architecture and Urbanism, University of Brasilia, Brasília 70904-108, Brazil
}

\begin{abstract}
Brasília, born of the urban plan by Lúcio Costa and of the unexpected concrete structural forms designed by Oscar Niemeyer, knew how to adapt to the new forms that came from the country's religious syncretism. This article aims to compare, through religious symbolism, structural forms and architectural spaces, two sacred monuments: The cathedral of Brasília (1958-1967) and the stupa of the Tibetan Buddhist Center, inaugurated in 2006. The millenary construction form of the stupa, one of the primordial sacred structures for all Buddhism traditions, the sacred symbol of enlightenment, must obey some construction rules according to its lineage's Buddhist tradition. In this way, the stupa is the opposite of a strong and fearless structural form embodied in the cathedral, with its 16 revolution hyperboloid concrete pillars and its subterranean entrance. Although built in concrete both are unusual forms of architecture with distinct spatial conception and sculptural form structures. While respecting religious differences, it is noticeable a real commitment between form and structure, volume and religious symbolism. At the conclusion, it is perceivable how distinct forms - the Cathedral and the Stupa - can respond in analog manners to the necessity of a gathering space where visitors go in search of expressing their faith. Along with them, Buddhism and Catholicism are rooted in Brazil's new capital.
\end{abstract}

Key words: Religious architecture, structural form, cathedral, stupa.

\section{Introduction}

Forty-six years stand between the sculptural monument of the Brasilia Cathedral and the Stupa of the Brasilia Tibetan Buddhist Center. In the city planned by Lúcio Costa and innaugurated on April 21, 1960, to be Brazil's new capital, Architect Oscar Niemeyer's signature genius makes itself present in several administrative, cultural and religious buildings, especially in the Our Lady of Aparecida Metropolitan Cathedral.

The 2000 census showed that in Brazil, a mostly Catholic country, there is a rise in religious diversity, and among eastern religions, Buddhism stands out. There are over 200,000 practitioners in Brazil, Centers with resident Lamas and local meeting temples throughout the nation's territory. The largest number

\footnotetext{
Corresponding author: Cláudia Estrela Porto, Ph.D., professor, research field: structure. E-mail: claudiaestrelaporto@gmail.com.
}

of Buddhists is concentrated in São Paulo, due to the many people of Japanese descent in that state. Other Buddhist schools, however, such as the Tibetan, are beginning to gain strength in many regions. In Brasilia, the Tibetan Buddhist Center Kagyü Pende Gyamtso ("An Ocean of Benefits"), founded on May 14, 1987, through the initiative of some Brazilian adepts and in the oral transmission lineage of Shangpa Kagyü ${ }^{1}$, has the goal of studying and propagating Buddhism and

\footnotetext{
${ }^{1}$ A Tibetan Buddhist lineage which had an important role in the transmission of the Tantric teachings. Although it is close to the Dakpo Kagyü school, the two should not be confused. It was founded by Khyoungpo Neldjor (978-1079), who traveled to India in order to receive the teachings of Niguma, Naropa's sister. The Shangpa Kagyü school had among its spiritual leaders Kalu Rinpoche (1905-1989), who founded several centers in the West, including the Tibetan Buddhist Kagyü Pende Gyamtso, in Brasilia. Bokar Rinpoche, Kalu Rinpoche's successor, assumed the spiritual continuity of this school until 2004, when he passed away. The new incarnation of Kalu Rinpoche was born in 1989, and was engaged in the three-year, three-month and three-day retreat, which ended in 2008, at the Bokar Rinpoche monastery, in Mirik, northern India.
} 
particularly the Vajrayān ${ }^{2}$ in its religious, philosophic, artistic and cultural aspects.

This article intends to show that these two sacred monuments, the Cathedral and the Stupa built in the CBTKPG (Tibetan Buddhist Center Kagyü Pende Gyamtso), go beyond the fulfillment of their spiritual functions, and enrich the architecture of Brasilia, with their surprising forms, full of symbolism. On the one hand, the free forms of the Cathedral express its strength through an innovative structure, and on the other, the sacred symbol of Enlightenment, built according to rules established in the Buddhist tradition, perpetuates the ages-old building type.

Brasilia, a futuristic and modern city, is open to this new building just as the nation is to a religious syncretism. The detailed study of the structural conception in the Cathedral and in the Stupa will provide invaluable elements to foster an understanding of these architectural forms, so different from each other, yet responding in a similar way to the necessity of a place for the faithful to withdraw into and demonstrate their faith.

\section{Brasilia Cathedral}

The daring structures in religious monuments built throughout history have always reflected the technical and constructive progress of each age. When thinking about the Brasilia Cathedral, Oscar Niemeyer wanted his design to embody every possibility offered by reinforced concrete and, by means of its lightness, to showcase contemporary technique. The "slender columns, extremely slender, prove how technique

\footnotetext{
${ }^{2}$ Or Tantrayana (Skt.), also known as the "Diamond Vehicle", Vajrayana is the name of the third vehicle of Buddhism, in the Indo-Tibetan tradition, after the Hinayana and the Mahayana. It is a natural follow-up of the Mahayana, when this vehicle adopts the methods and means adequate do develop rapidly the supreme knowledge and attain the Enlightenment in few life-cycles, if not in a single one. In this tradition, it is taught that the Buddha-nature is identical to the essential nature of mind, having the qualities of emptiness-clarity and non-obstruction. There the authors also conduct the Paramita practice with the techniques corresponding to the phases of creation and wholeness, drawing out the resources of body, word and mind.
}

controls reinforced concrete and how the latter adapts mildly to all our fantasies" [1], my translation.

The Brasilia Cathedral was intended to hold 4,000 attendees, but its architectural ensemble includes other elements, such as the reflecting pool, the baptistery, and the campanile [2]. This article will emphasize only the Cathedral building, analyzing it under the perspective of its structure.

\subsection{Sitting}

The urban plan for Brasilia, conceived by Lúcio Costa, is in the shape of an abstracted airplane: two imaginary axes, called "highway axis" and "monumental axis". The huge monumental axis is slashed perpendicularly by a long spine, arched following the topography (the residential-highway axis), along which the superblocks unfold. Along the monumental axis were placed the government buildings, administrations, palaces, ministries, the theater, the broadcast tower, the Cathedral among others. The Cathedral sits on its own plaza, on the lower stretch of this axis, together with the ministries and agencies, it forms a large esplanade terminating at the Plaza of the Three Powers (Fig. 1).

\subsection{Building Phases}

Construction of the Cathedral, following Oscar Niemeyer's design, began on August 12, 1958, amid the building campaign of the new capital. In 1959, before the inauguration of Brasilia (1960), its structural form (reinforced concrete piers, shaped as a ruled revolution hyperboloid) was already finished (Fig. 2). The lateral sheathing between the piers was undertaken only in 1967, shortly before its dedication, on October 12 of the same year (Fig. 3). On this occasion, the Cathedral received the image of Our Lady of Aparecida. From 1969 to 1970, the precinct was completed with the construction of the reflecting pool around the Cathedral, the baptistery and the campanile. Inaugurated on May 31, 1971, it was repaired in 1987, on a design by Niemeyer, when its 


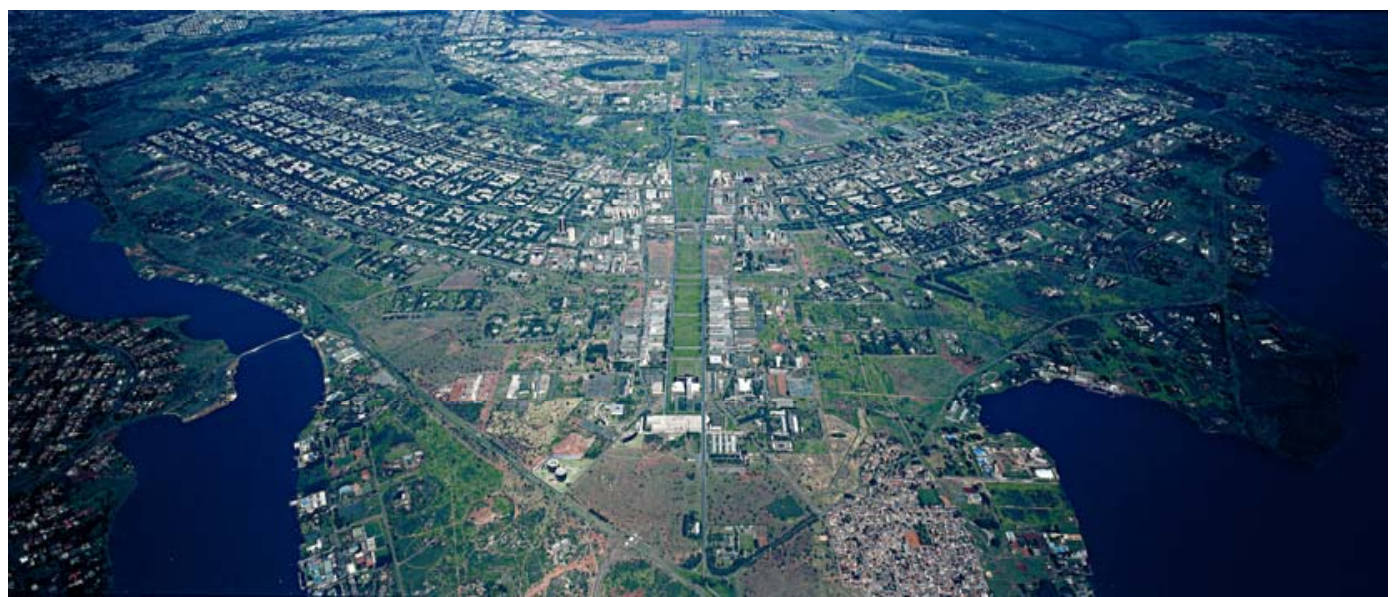

Fig. 1 "Pilot Plan" of Brasilia: the cathedral is on the Monumental Axis, in the picture, it is indicated by the small dot to the left of the central axis, behind the Ministries (photo: João Facó).

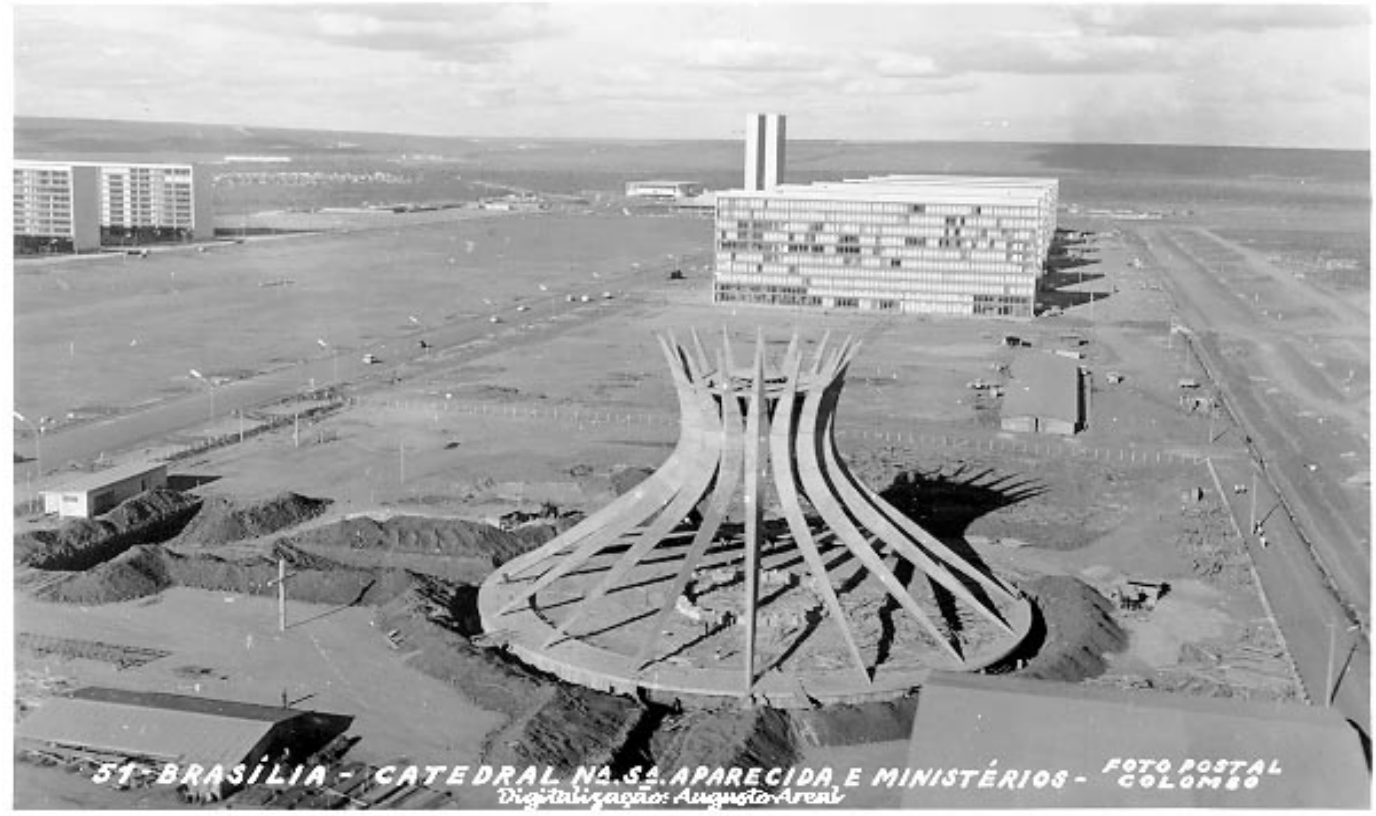

Fig. 2 Brasilia Cathedral, with the structure just poured, before the inauguration of Brasilia (unknown photographer).

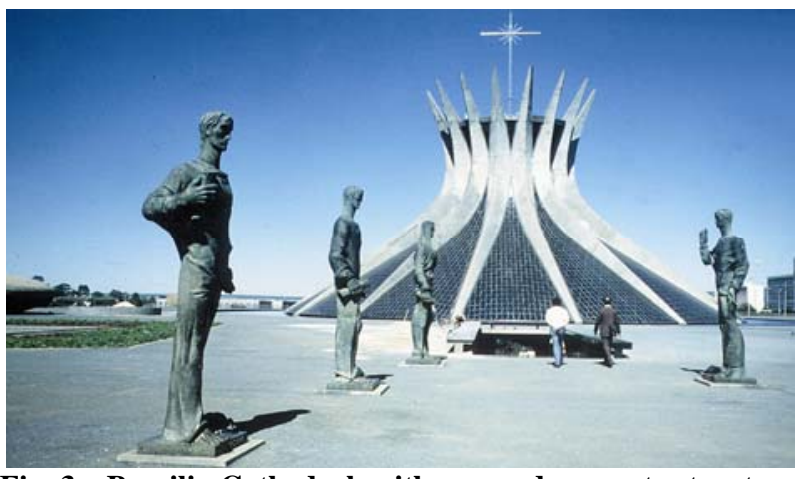

Fig. 3 Brasilia Cathedral, with exposed concrete structure and lateral sheathing between the piers (photo: Alexander Fils). structure was painted white and the colored stained glass panes, by Marianne Peretti, were added beneath the mullions of the nave (Figs. 4 and 5). Although it stood for eight years (1959-1967) under the elements, the structure of the nave has not received significant interventions so far. Both repair campaigns (1987 and 2000) targeted only aesthetic aspects, with no direct intervention in the structure of the Cathedral's nave. From a structural point of view, only the second campaign (2000) involved the structure of the reflecting pool, renewing the waterproofing of its 
joints, and the baptistery slab, with the restoration of corrosion points in the slab's reinforcement.

\subsection{Form and Symbolism}

Aware of the fact that a cathedral requires broad spaces, Niemeyer creates a volume generated by its structural elements, by means of which he reaches a unity of form, structure and religious symbolism. As he ventured saying himself: "when the structure is ready, the building is finished" [3].

Even though structural form may define a building, in the Brasilia Cathedral Niemeyer also demonstrates his genius for architectural composition. Structure and volumes interact to create spaces with so strong a religious connotation that the images of the cross and of saints may be eliminated. The curved columns pointing to the infinite may be seen as a gesture of supplication and communication with God. The regularity of the façade obtained with the circular

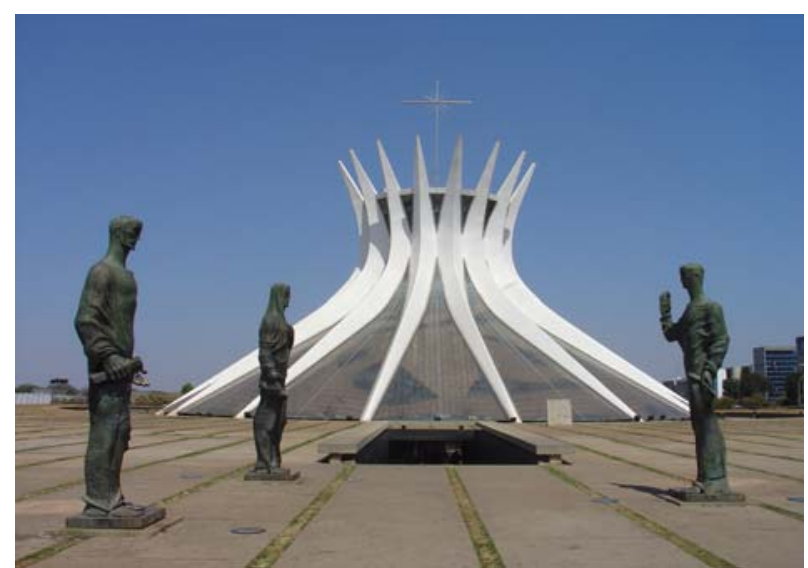

Fig. 4 Brasilia Cathedral, present state: view towards the outer access ramp. form recalls the idea of purity (Fig. 6).

Niemeyer lowers the nave $3 \mathrm{~m}$ below the esplanade floor and makes it accessible through a down ramp, followed by an underground gallery. Alfredo Ceschiatti's Apostle statues, lining the ramp, protect the devotees entering this dimly lit space so that, after the redemption, they may reach the wholeness of the nave's interior, bathed in daylight and colors. This magistral play of light and darkness, nave and gallery, affords the faithful a space of withdrawal, hope and peace.

Around the nave and likewise sunken, are the sacristy, ancillary rooms for religious service and offices, linked to the main building through an underground corridor. This solution is also employed to connect the baptistery, placed outside the temple. Externally, however, the baptistery can also be accessed from a spiral stair as well as from a passage located in the tunnel leading to the church space.

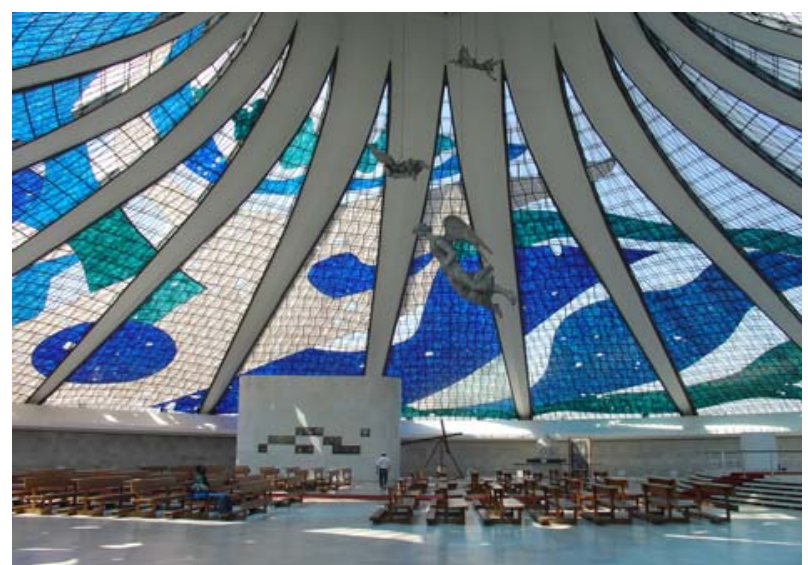

Fig. 5 Brasilia Cathedral, present state: interior devotional space bathed in daylight.

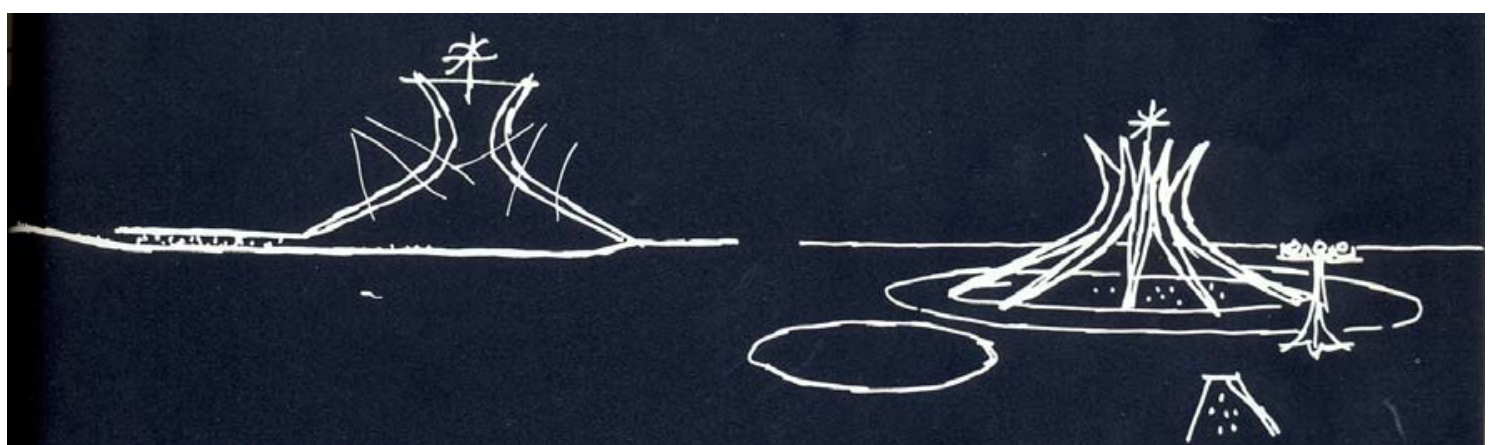

Fig. 6 Diagram by Oscar Niemeyer showing the importance of daylighting in the temple's interior and the sculptural shape of the Cathedral, with the campanile and baptistery [4]. 


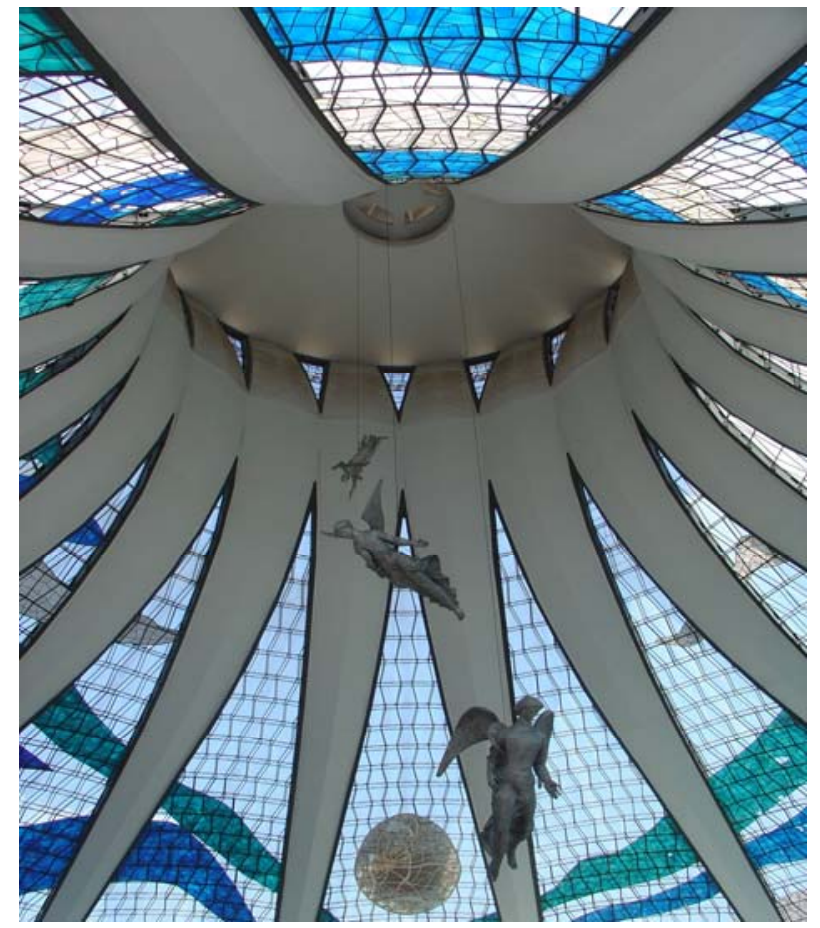

Fig. 7 Brasilia Cathedral, present state: view towards detail of the compression ring, roof slab and glazed curtain walls among the piers.

\subsection{Structure of the Cathedral}

The structural form of the Brasilia Cathedral stems from the technical capabilities of reinforced concrete and from the genius in Engineer Joaquim Cardozo, who made the calculations for the structure at the time of its construction. The 21 40-meter tall hyperboloids, as had been intended originally by Niemeyer, were reduced, for aesthetic reasons, to 16 30-meter tall piers. Likewise, the concrete ring forming the base on the ground and serving as a footing, initially planned to be $70 \mathrm{~m}$ in diameter, was altered for reasons of stability. It was reduced to $60 \mathrm{~m}$, and the top ring, a support to ensure the tying together of the piers and the rigidity of the structure, was lowered $10 \mathrm{~m}$ from the top of the structure, enhancing the latter's light weight and transparency (Fig. 7).

Among all possible geometric surfaces, Niemeyer chose, for the structural form of the Cathedral, the ruled revolution hyperboloid, a surface generated by a slanting line moving along two circles, the meridian of this surface being a hyperbola. This surface is also considered a rotation surface, since its face is the result of the rotation of a planar curve (the meridian) around a line situated on its plane, and with the meridian convex in relation to the axis of rotation.

The 16 curved piers, revolution hyperboloids, represented a challenge to then-current structural concepts, as they find stability in the circular traction ring on which they stand, and also in the compression ring, placed not atop the piers, but $10 \mathrm{~m}$ below their top (Fig. 8). The upper ring is not visible, as it runs through the piers, the lower ring, at floor level, absorbs the traction stresses, thereby functioning as a tie-beam, reduces the load on the foundations, which

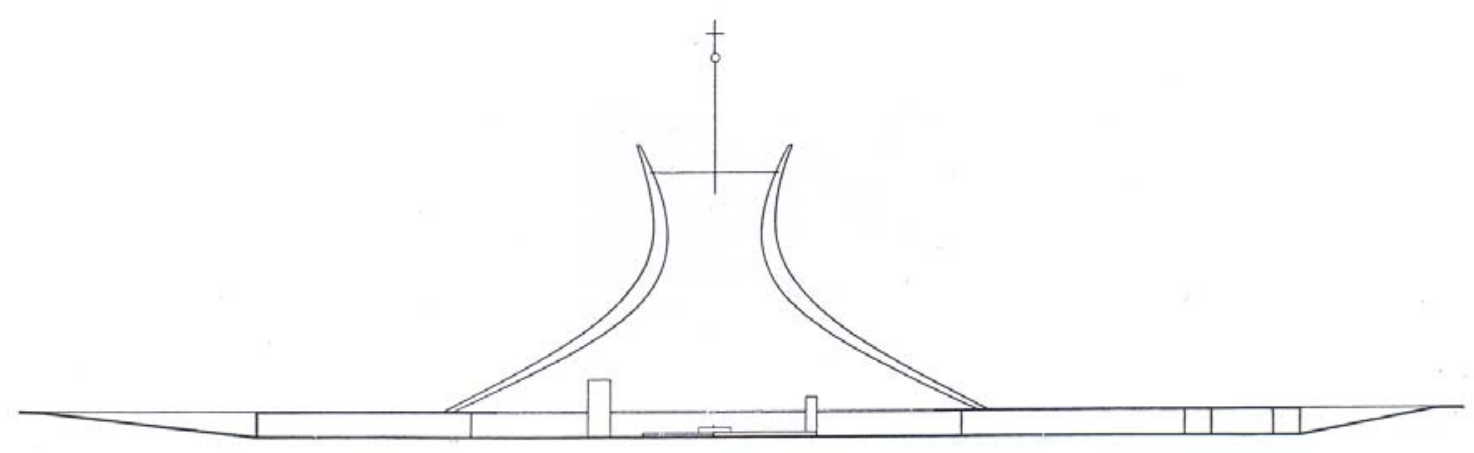

CORTE TRANSVERSAL

TRANSVERSAL SECTION

Fig. 8 Diagrammatic section through the Cathedral, showing the hyperbolic arcs, the top slab as a base for the cross, also shown are the sunken spaces of the entrance, nave and sacristy [5]. 
then resist only vertical stresses. The roof slab has only a sheathing function, allowing for natural ventilation through its central opening [6].

The structural system of the Brasilia Cathedral is detailed below (Fig. 9):

The structure is made of only 16 curved piers, with a near-triangular, hollow cross-section. The cross-section of the base is solid, shaped as a quadrilateral consisting of two triangles linked through their common, $65 \mathrm{~cm}$-wide base, one being 20 $\mathrm{cm}$ tall, the other 50 . From a statics point of view, this section was considered an articulation, the $76 \times$ 1"-gauge (probably of 50-Megapascal steel), making up $16 \%$ of the cross-section area, notwithstanding. Along the first $7.4 \mathrm{~m}$ the axis is straight and solid. From this point onwards, the section is hollow and wedge-shaped, leaving the side walls with a thickness of $15 \mathrm{~cm}$. The maximum plan diameter at the base is $60 \mathrm{~m}$ (on axis). At a height of $20.4 \mathrm{~m}$ from the floor the least diameter is to be found, and the piers touch each other. An embedded beam with a section of 22 by $90 \mathrm{~cm}$, not seen from the outside, ties the piers together, giving rigidity to the assembly. At this point the cross-section of the piers is largest, $2.05 \mathrm{~m}$ tall and $2.58 \mathrm{~m}$ wide. The diameter at the point of contact is reduced to a minimum of $26.28 \mathrm{~m}$. From there up, the piers spread out from the axis, reaching a height of $30.6 \mathrm{~m}$, with an outer diameter of $22.6 \mathrm{~m}$. At a height of $20.4+4.85=25.25 \mathrm{~m}$ there is a roof slab, $20 \mathrm{~cm}$ thick. A central oculus, with a diameter of $3.1 \mathrm{~m}$, is covered with a $4 \mathrm{~cm}$-thick spherical slab, having an inside radius of $6.15 \mathrm{~m}$. The remaining $4.1 \mathrm{~m}$ are solid and have a straight axis. The 16 piers stand on a circular beam of $200 \times 5 \mathrm{~cm}$, reinforced top and bottom with $40 \times 1$ "'-gauge bars. This slab functions as a large tie, and runs to the center of the church, with a grid-like structure shaped as a circular crown on a module of $100 \times 100 \mathrm{~cm}$. The distance between the piers at their bases is $11.8 \mathrm{~m}$, affording wide panes of glazing. The solution for the sheathing of these panes represented a big construction problem, since there was no way to fabricate curved glass leaves of this size, and Niemeyer would not accept their subdivision with mullions, which would have debased his conception of lighting [7].

Architect Carlos Magalhães, in charge of construction, describes the foundations and structure of the Cathedral, as follows:

On the foundation blocks stand 16 piers, one on each block, which support the ring from where spring the 16 columns marking the structure of the Brasilia Cathedral. The traction ring is separated from the infrastructure piers with sheets of neoprene $(50 \mathrm{~cm} \times$ $50 \mathrm{~cm} \times 2.5 \mathrm{~cm})$. The function of this traction ring is to absorb horizontal stresses transferred from the 16 columns. The neoprene prevents any horizontal movement of the traction ring to be transferred to the infrastructure piers. The columns rise from the traction ring, solid and slender, reinforced with seventy 1"-gauge, 50-Megapascal bars. From there their dimensions increase, and the structural calculations provided for lost caissons, which avoid an excessive increase in the weight of the member, preserving the size determined by the architect as well as the stability of the building. The 16 columns, even as they rise in height, draw near each other, and, after touching, keep rising, moving away from each other, solid again (Fig. 10). On the spot where they touch, the columns rest on a ring which works in compression and prevents them from closing in Ref. [8].

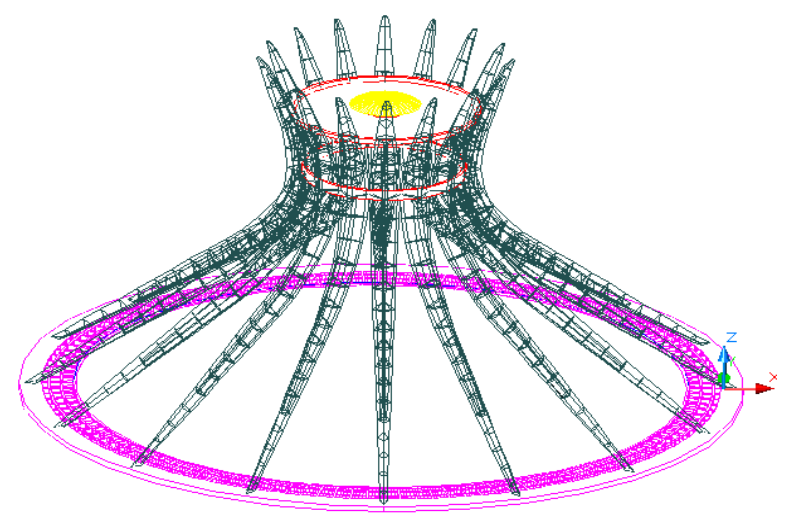

Fig. 9 Structural system of the Cathedral: tracion ring, gridlike structure, piers, compression ring and roof slab [8]. 


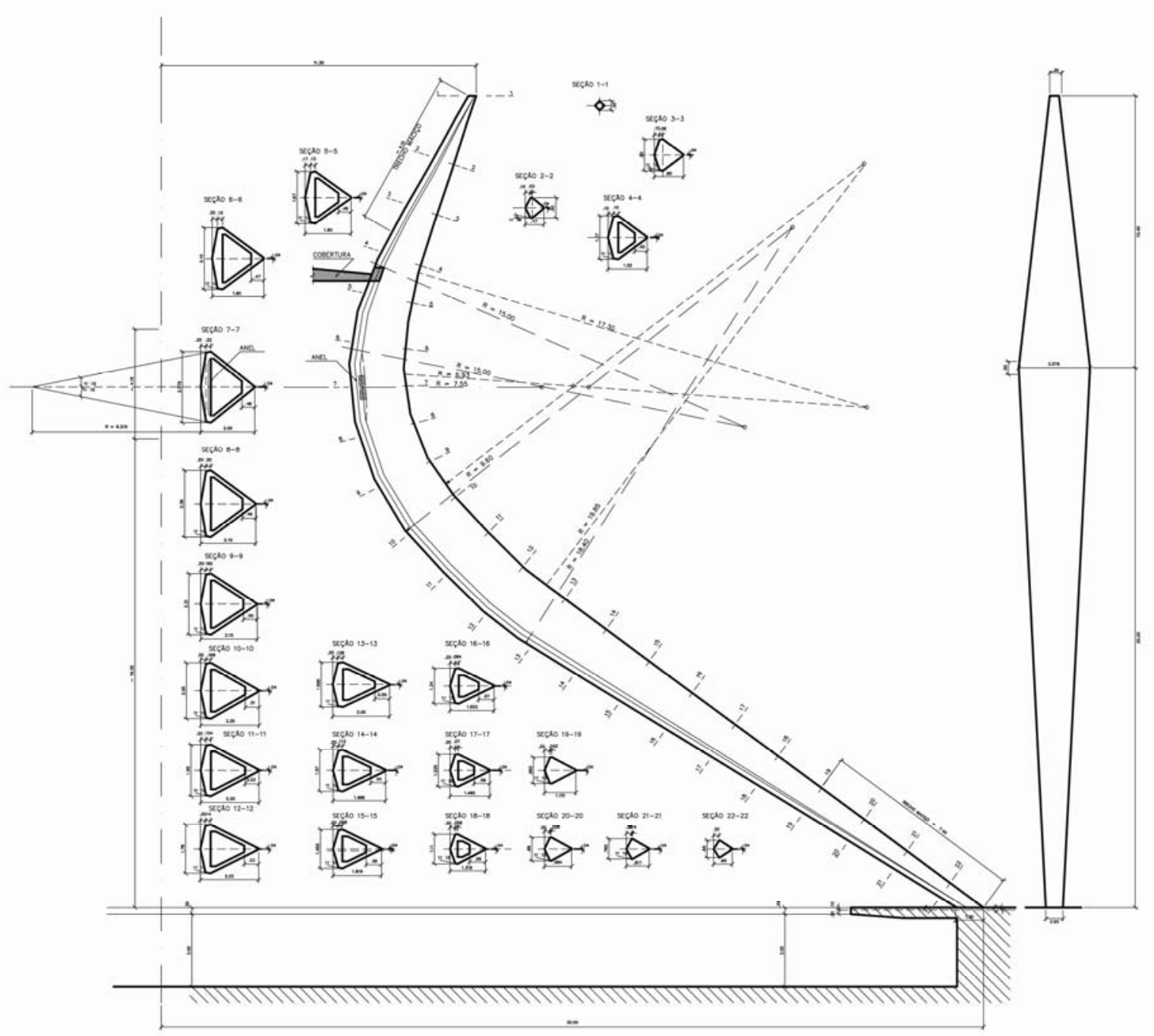

Fig. 10 Cross-sections of the pier-copy of original work [8].

The 16 piers are tied together with glazing panes, and their initial loads, as anticipated by Cardozo, would have been limited to the wind loads and to the light weight of plastic mullions. Afterwards, the solution proposed by Niemeyer, with a spatial frame, has allowed, besides directing the heavier loads to the ground, the mounting of two layers of glazing on the hexagonal structure of the lower and upper webs of the truss (Fig. 11).

\subsection{Structure of the Sheathing of the Cathedral's Nave}

Between the piers, a space frame (a three-dimensional truss) in steel, covered with glass panes, closes the structure (Fig. 12). Although this space frame is tied to the concrete structure by means of steel bars fastened along the piers, it is not supported on the piers, but directly on the ground.

The Cathedral's lateral infill, executed in 1967, in between the 16 curved, slender piers in exposed concrete, constitutes the first idea of using a space frame in the architecture designs for Brasilia. However, this is not the case of a "spatial node": the bars, made in $3 / 4$ "-gauge steel, are welded. The lower and upper web are made of elongated hexagons, horizontally sectioned, forming two wedges linked with diagonal braces. The proposed solution, a spatial frame, besides directing the heavier loads directly to the ground, also permitted the fixation of both layers 


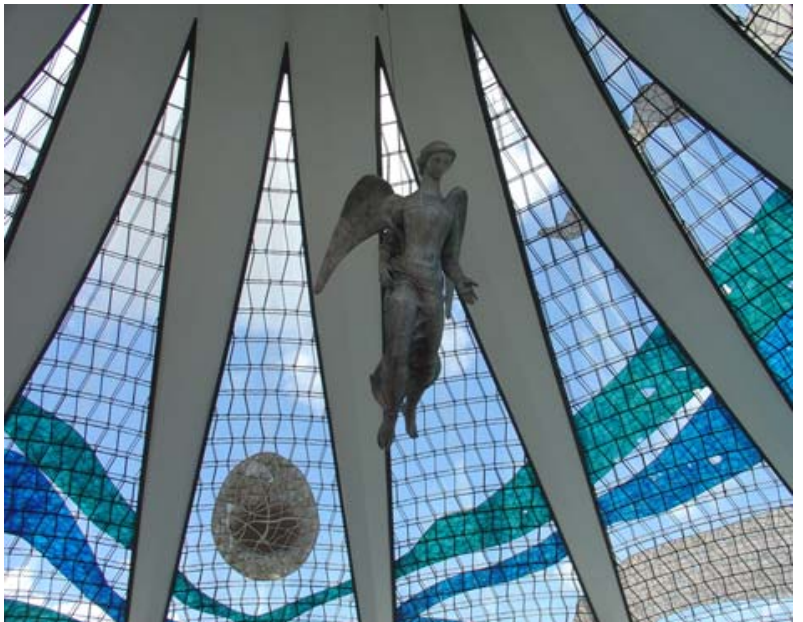

Fig. 11 The spatial frame between the piers allows the fastening of two layers of glazing on the upper and lower hexagonal webs of the truss (photo: author).

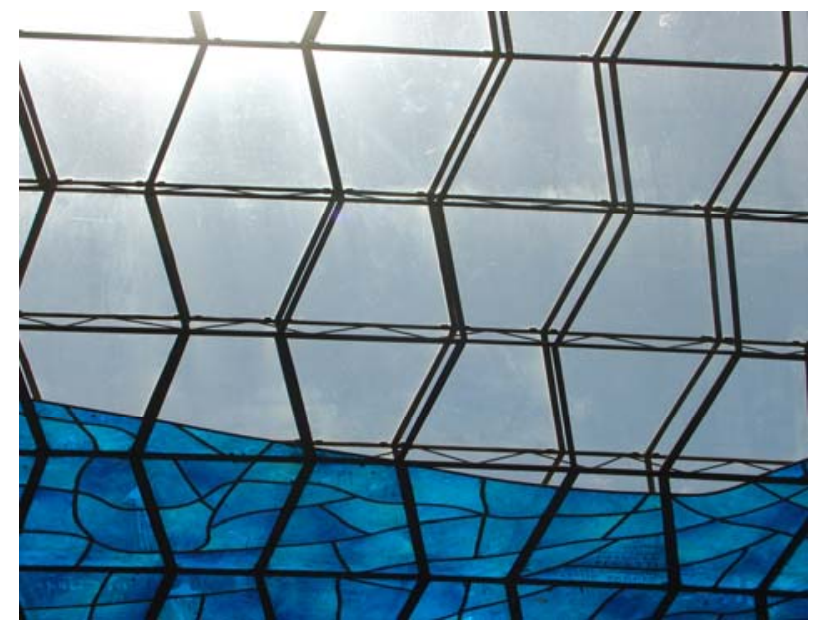

Fig. 12 Detail of the fastening of the glass on the spatial truss.

of glass, in the upper and lower hexagonal web structures.

The cathedral was designed to have a glass skin on both upper and lower webs of the spatial frame. At the time of its inauguration, however, only the glazing on the upper web of the structure comprised its sheathing. This tempered glass was mounted in neoprene mullions, placed on the metallic structure, allowing the glazing to displace independently of the latter. The glass for the upper sheathing was made especially for the cathedral, and the dimensions of each pane are rigorously identical. In 1987, during the repair work, the lower web was filled with Marianne Peretti's stained glass (glass fiber colored blue, green and white). These glass panes were pre-cut and pre-stained. Perhaps because of this, their lengths are different, which caused some of them to rupture because of differential movement, since this time they were fastened to the steel bars. The suction of hot air is made through the purpose-designed central opening of the cathedral.

The three-dimensional structure was delivered to the site in pre-welded stretches, and these were attached together on-site, forming 16 parts of $140 \mathrm{~m}^{2}$ each, shaped like a triangle with a $10 \mathrm{~m}$ base and $30 \mathrm{~m}$ height. The pronounced slope of the spatial frame and the fact that the metallic structure is not welded to the piers caused almost all of the load from this roofing to be absorbed by the ground on which it stands. The piers therefore receive only the wind loads, as previously estimated by Cardozo and a small part of the load from the glazing panes, which touch the pier's lower stretches.

\section{Stupa of the Tibetan Center Kagyü Pende Gyamtso}

Before analyzing the object, the Stupa of the Tibetan Buddhist Center Kagyü Pende Gyamtso, it is necessary to address the origin, types, symbology, proportions and dimensions of this building.

\subsection{Definition}

A form unique to Buddhist sacred architecture, the Stupa (Sanskrit; Tibetan chörten) is the highest symbol of Enlightenment, the representation of Buddha's mind, the primeval sacred structure of every Buddhist tradition. Built according to universal principles and made canonical through the blessings of the uninterrupted lineages of transmission of the teachings, the stupa converts offerings into merits which open the spiritual path and give birth to the aspiration for Enlightenment.

\subsection{Origin}

The origin of stupas goes back to pre-Buddhist times, and its hemispherical or conical shape over a 
round base conceivably descends from the tumulus, the earthen mound which every culture, since prehistory, has built on the spot of a grave [9]. With the development of civilizations, this mound became a building erected with durable materials, such as the dome sculpted over a square base, made in brick or stone, with a more or less researched ornamentation bestows it with an architectural character. In the center of the square base (that is, on the central axis of the building) is a reliquary intended to preserve the relics of saints or sacred texts.

Emperor Aśoka, who reigned in northern India in 3rd century BCE, is held to be the great propagator of this kind of structure. Tradition credits him with building 84,000 such stupas, but this number is probably more of a symbolic expression than a realistic assessment.

\subsection{Functions of the Stupa}

The stupa can have four functions: funerary monument, reliquary, commemorative monument and votive monument. The first two are very close: the stupas are real tombs when they hold complete remains, and they are considered reliquaries when they contain fragments of human remains or of other sacred objects. Several stupas do not contain any kind of relic and were built for commemoration and worship functions only, signaling and hollowing the sacred spots of the life of the Buddha (Lumbini, Sarnath, Bodhgaya and Kuśinagara). Finally, the stupa bears, in the eyes of Buddhists, an intrinsic religious value, whence it is also considered a votive element.

Thus, according to the nature of their function, stupas can be arranged in four categories: the dhatu-ćaitya, which hold relics, the paribhoga-ćaitya, which contain objects previously owned by the Buddha, the dharma-ćaitya, which expound Buddhist doctrine, and the uddeśika-ćaitya, which commemorate the parinirvāna (passing) of the Buddha, ćaitya being a Sanskrit word for shrine.

For the purpose of the current study, the stupa will be considered as a reliquary monument typical of Buddhism, originally built in stone by the lay congregation, on a suggestion from the Buddha Śākyamuni $^{3}$ to hold his relics. It later became a building intended for the relics of other beings who achieved great spiritual achievements, as well as for texts and statutes. These buildings are erected in memory of a Bodhisattva or to protect from evil spirits places traditionally considered dangerous, such as crossings, bridges and mountain slopes. Just like statues, the stupas which represent the mind of the Buddha are consecrated and contain, within their structure, the tree of life (Tibetan srogshing) - a tree trunk with relief inscriptions of religious formulas, relics, mantras ${ }^{4}$, sculptures, sacred books and spices.

\subsection{Placement within the Monastery Compound}

In the time of the Buddha Śākyamuni, wandering monks, members of the Sangha (monastic community) did not have a fixed dwelling place. They remained in open air, in the forests, beneath trees, in mountain caves, cemeteries, etc.. During the three months of Monsoon, however, when it was not possible to wander, they had to seek temporary refuge in caves or sanctuaries. These buildings were, initially, bamboo huts or simple wooden buildings, but they soon became monasteries. The monastic precinct comprised several private and common spaces. Besides serving their originally-intended purposes (a place for

\footnotetext{
${ }^{3}$ Name given, in the Mahayana tradition, to the historical Buddha, Siddharta Gautama (566-486 BCE), the son of a sovreign of the Śakya kingdom. Both for the Hīnayana and Mahayana schools, the historical Buddha was not the first, and will not be the last, to manifest himself on this Earth. He is the seventh on the Hinnayana list and the fourth according to the Mahayana, and will be followed by the Maitreya Buddha in the future.

${ }^{4}$ Sacred formula, verbal and mystical chant, invoking the deity. Mantras (Tibetan ngak) are Sanskrit syllables or words used to call on the power of the word or energy of one particular deity. The devotee need not know the meaning of the words, since the very sound of the mantra helps transform his own energy, hence his own awareness. The mantras are the oral form of waking reality, the ultimate divine sound. In this way, the mantra bears a particular blessing, a beneficial force which is inherent to it. Chanting, listening to, watching or touching a mantra allows one to enter the current of this force.
} 
meditation and religious ceremonies), monasteries, especially the most important ones, became during the first centuries of the Common Era prestigious educational institutions, academic centers for Buddhist learning.

The earliest monasteries were made of decaying materials, such as wood or bamboo, and almost every one of them was destroyed or rebuilt several times, which makes it difficult to identify their original core. Fortunately, the rock-cut caves created since 3rd century BCE provide elements regarding the evolution of monastic architecture. Althouh the monasteries (or temples) within caves are not buildings, and therefore not architecture, in the strict sense, they establish the original layout in the disposition of cells, isolated or grouped together.

It is necessary, therefore, to study a few of these buildings (particularly the Ajanta and Ellora caves, in India) in order to understand the evolution of architectural spaces in the built-up monasteries and the relationship among them (entrance piece, piers, colonnade, courtyard, porch, cells, nave, stupa and Buddha image).

Due to a long tradition, the Buddha image initially occupied a secondary position and was placed within the stupa built inside the monastery. As the popularity of the image grew, this replaced the role of the stupa in the shrine, and the latter was moved outside the precinct.

In the same way as for the temple, understanding the stupa involves knowing its architectural evolution in Asia. Although our study is restricted to the essential elements of the Tibetan Stupa, the study of the evolution of the forms and plan of the stupa, originating from the alterations introduced by each culture, tell of the migration of Buddhism. Without delving into detail, it should suffice to say that during the first centuries of its existence, Buddhism expanded to the Himalayan regions, in northwest India. Afterwards, it spread to the northeast, and from there the Indian emperor Aśoka introduced it to Nepal.
Only after several centuries it reached Tibet. In the beginning of the Common Era it reached China, from where it spread to Korea, then in 6th century to Japan.

\subsection{Temple, Player Banners and Stupas: Elements of the Monastic Compound}

Buddhism, having a vast view of the Universe, conceives of innumerable extra-temporal worlds, that is, worlds which are above the plane of enlightened manifestation, called "pure lands", over which reign emanations of Buddhas as deities. The palace of the deity is called "mandala". The Tibetan temple is a reflection, for human eyes, of the heavenly mandalas perceived only by the dwellers of the pure lands. The name used by the Tibetans to refer to a temple, lhakhang, embodies what it represents, as it means "Dwelling (Khang) of the Gods (Lha)".

For the Tibetans, the temples remain what they always had been: the house of godly reality or enlightened reality, before which they come to prostrate, make offerings and say prayers. With the destruction of nearly all the temples in Tibet, during the Cultural Revolution of China, many Tibetan Lamas in exile, using determination and courage, rebuilt these structures in India, Europe and America.

Although the temple is a heavenly reflection, its earthly building requires great care as well. The shrine, in order to emanate all its power, needs a special environment. While Christian, Jewish and Islamic sanctuaries are typically built in the middle of cities, the Buddhist temple, as it is in the first place part of a monastery, is traditionally found apart from settlements, preferably in a wild and isolated place.

The reason for this goes beyond the mere intention of integrating architecture and landscape, and of providing a feeling of strength and power. It is necessary to add a certain knowledge of telluric forces (which were also taken into account in the construction of churches during the Middle Ages), with the respect for an invisible population made of 
different categories of spirits living in mountains, valleys and waters.

Around the temples, prayer banners and stupas enhance and support its splendor. From afar, when people draw near a temple or monastery, the first thing people see are the multicolored prayer banners waving in the wind. These banners, originally in bright colors which became duller with the action of the elements, are covered from top to bottom in sacred writings. The stupas, due to the symbolic complexity of their construction, will be analyzed in more detail below.

\subsection{Types of Tibetan Stupas}

There are different kinds of stupas, ranging from a few centimeters in height to several meters. Their forms vary just as much, and the authors can count, among the Tibetans, eight kinds of stupa. According to tradition, after the cremation of the Buddha, his relics were split in eight parts and distributed to the eight kings who had come to pay homage to him: Ajātaśatru, King of Magadha, Licchavi of Vaiśālī, the Śākya of Kapilavastu, the Buli of Allakappa, the Koliya of Rāmagrāma, the Brāhmana of Vatthadvīpa, the Malla of Pāvā and the Malla of Kuśinagara.

These were the relics which ended up being enshrined in the first eight stupas (Fig. 13), built according to the episodes of the life of the Buddha: his birth, awakening or enlightenment, the first sermon or teaching, the descent of a celestial kingdom, the performing of miracles and prodigies, the reconciliation of a schism in the Sangha, the voluntary prolongation of life and his death [10]:

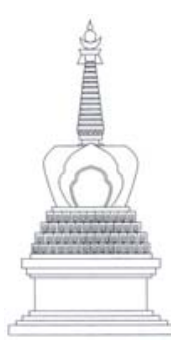

1

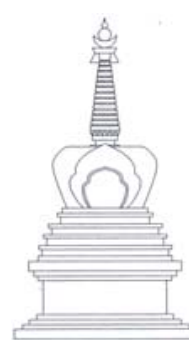

2

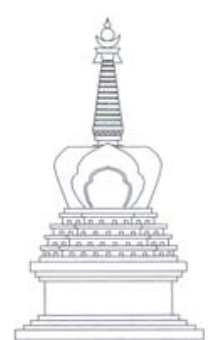

3

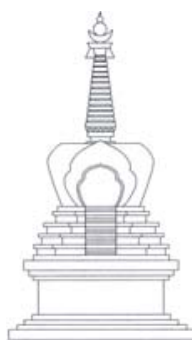

4

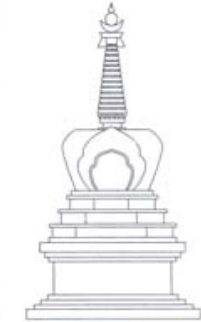

5

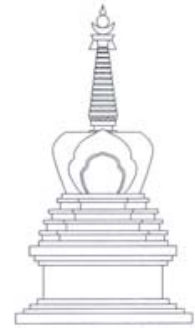

6

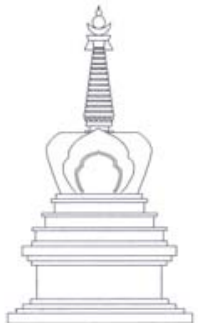

7

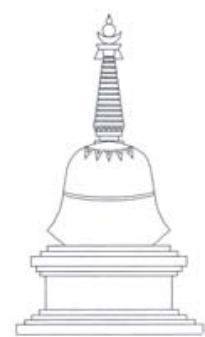

8

Fig. 13 The eight types of Tibetan Stupas [11]. 
Tibet. Under its apparent simplicity, the Stupa is a building that relates to a complex symbolism, difficult to explain in few words. The authors can say that it corresponds to the different aspects of progression towards Enlightenment, which can be attained by every being.

To showcase this symbolic richness, represented in the different architectural elements of the Stupa, the authors can say that the plinth-(1), which supports the building, represents the ethics of the "ten virtues" upon which every spiritual practice depends, the three staircases - (2) of the base stand for the Three Jewels, under the protection of which Buddhists place themselves - the Buddha, the Dharma (teachings), and the Sangha (community of believers), the vase-(3) represents the "seven branches of awakening", the thirteen wheels - (4) designate the "ten stages" and the "three perfect applications", the moon-(5) represents the elimination of all suffering, the sun-(6) symbolizes the unfolding of a thousand lamps of compassion, and the jewel at the top-(7) stands for the realization of all wishes (Fig. 14).

The symbolism of this architectural image functions simultaneously at different levels. If the square base represents dominion over desire, the vase, dominion over form, the piled umbrellas, domain over no-form, and the central axis, Mount Meru, represented by the Tree of Life - a sandalwood or juniper trunk, ritually cut, which passes vertically through the center of the stupa-other symbolisms can also be read. At the level of archetypes, a stupa embodies five different geometric shapes referring to the five elements of which the universe and all its atoms are made. The square or rectangular base is the Earth and the Buddha Ratnasambhava, the hemispherical dome symbolizes water and Akshobhya, the conical or pyramidal spire symbolizes fire and Amithāba, the canopy of the upper part is air and Amoghasiddhi, the Sun and the Moon are the female and male essences, and the volute at the top (nāda), the space and Buddha Vairocana.
In another symbolic interpretation of its form, the dome would represent nirvāna, the square base is the discipline, and the superimposed umbrellas at the top are a royal emblem, a symbol which might remind of the Buddha's princely origins. Besides, the overall shape of the stupa is reminiscent of the sitting Buddha It is held that, when people see such harmoniously balanced forms, people receive subtle benefits, experienced as a sensation of peace, well-being and wholeness. The several levels and steps of a stupa also correspond to the different levels of the spiritual path which eventually reaches the ultimate Enlightenment.

In addition to its apparent structure, the stupa is equally important for what it contains the authors do not see: several consecrated objects and relics. From there stem its force and power and what bestows it

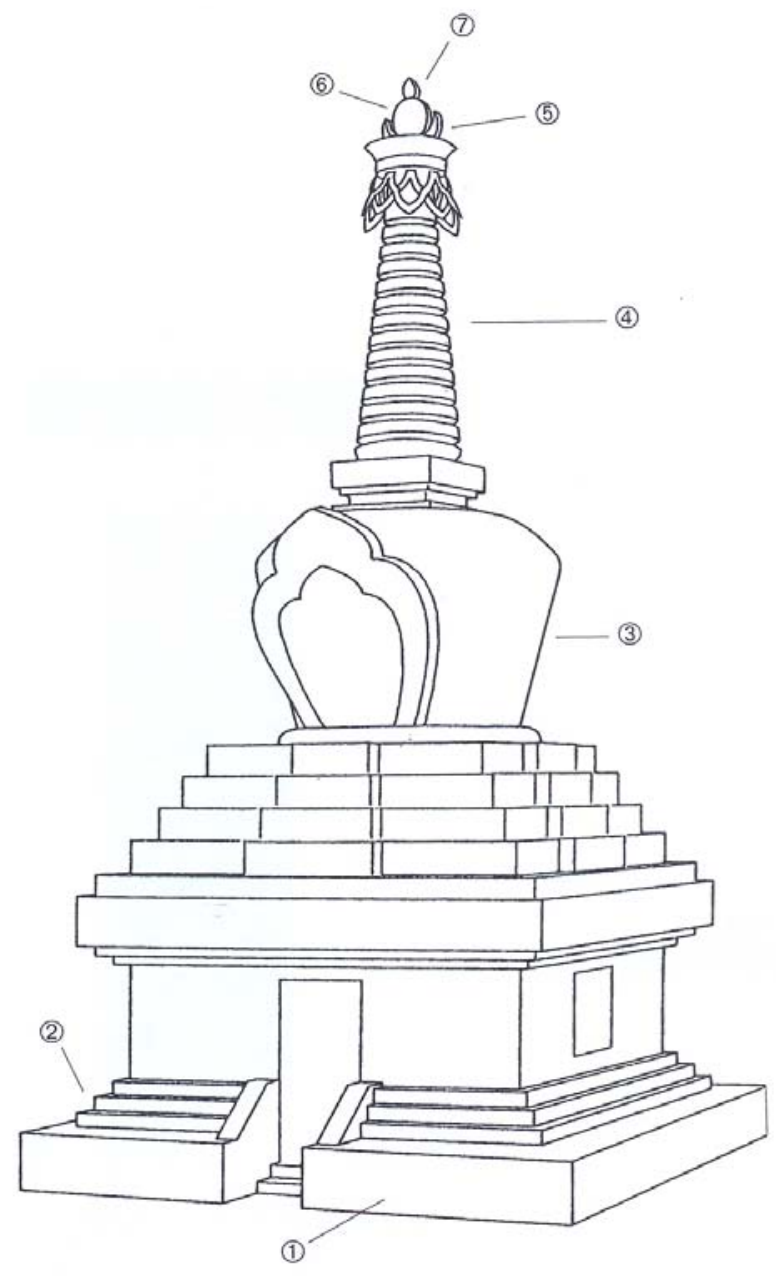

Fig. 14 General symbolism of the stupas [12]. 
with a function, that of transmitting the Buddhas' blessings to all who see it, touch it, or think of it. It is said that the stupa is the support for the mind of the Buddha, in the same way as the sacred texts are the support of his word, and the statues the support of his body. Two stupas can be linked by a wall of prayers (mani), where there will probably be inscribed the mantra of Avalokiteśvara ${ }^{5}$ (Om Mani Peme Hung).

The monks and lay-people walk around a stupa clockwise, following the course of the sun. This is what is called a circumambulation. Through this action, typically accompanied by the chanting of a mantra, respect is paid to the stupa while filling oneself with its blessing. Thereby, one accumulates merits (positive karmic tendencies), even if the action is done involuntarily. The stupa is also a place for offering lights. The pilgrims, during the circumambulation, light candles or butter lamps while chanting prayers. This practice helps keep the image of Enlightenment and all it represents at the center of our attention and is, therefore, very beneficial both as a conscious action and for the subconscious. Although a Cartesian mind could see in several Tibetan Buddhist aspects the expression of a superstition, a Buddhist mind will see in the same action the interaction of mind and matter, the two being not-separate.

\subsection{Stupa of Enlightenment}

Architecture has been an effective means of expressing religion. In Tibetan Buddhism, any virtuous action with respect to the Three Jewels - Buddha, Dharma and Sangha - be it great or small, contains within it incommensurable merits. Among them, the construction of stupas is considered

\footnotetext{
${ }^{5}$ Avalokiteśvara (Sanskrit) or Chenrezi (Tibetan): The lord or Bodhisattva of Great Compassion, the Lord-who-looks-down-from-above, also called Lord of the World. It is the great Bodhisattva who personifies the compassion, the most popular Bodhisattva in the Mahayana tradition, also known as protector of the world or He-who-holds-a-lotus in his hand. The Dalai Lamas of Tibet are considered bodies of emanation of Avalokiteśvara, as well as the Gyalwa Karmapas, of the Karma Kagyü lineage.
}

one of the most virtuous and meritory.

In Tibet and in all regions influenced by Tibetan Buddhism, the symbolism of the stupa becomes Mahāyāna ${ }^{6}$ and Tantric. The authors have seen that each of the eight Tibetan Stupas holds a specific symbolic meaning, but the current study will address the Stupa of Enlightenment, built according to the strict construction norms of Tibetan Buddhism, on the site belonging to the Buddhist Tibetan Center Kagyü Pende Gyamtso, located in Sobradinho II, one of 19 metropolitan areas of the Federal District (Fig. 15).

For the construction of the stupa one needs, besides the knowledge of its essential constituent parts, such as the dome or the funerary chamber, the reliquaries, foundations, circling terraces, the base used as a shrine, the stupa's own superstructure, also an understanding of dimensions, materials, of how to stucco or finish a surface, of interior spaces, of decoration and of the site where it will be located.

The main component of the stupa is its hemispherical dome, covering the urn which contains human ashes and relics. The second part comprises the foundation on which the dome sits, and the third is the niche where the pole with umbrellas is inserted, indicating symbolically its honorific value.

Stupas come in all sizes, but Fig. 16 shows the proportions to be used when building the Enlightenment Stupa. It can be seen that the three parts mentioned above have the same height in proportion, and that this proportion is maintained at the base of the dome and in the great lotus.

The stupa of Enlightenment, as shown in Fig. 17, is made of 24 parts, each one of them rich in symbolism. The analysis of several texts shows some degree of variation, but the purpose remains the same: the stupa shows the way to liberation. Before building the

\footnotetext{
${ }^{6}$ Buddhist current which encompasses several schools of the Great Vehicle, having as a principle the ideal of the Bodhisattva. The Mahayana or Great Vehicle is based on the realization of emptiness and compassion. That who follows it, the Bodhisattva, seeks to attain the perfect state of Buddhahood in order to free all beings from suffering and establish them in happiness.
} 


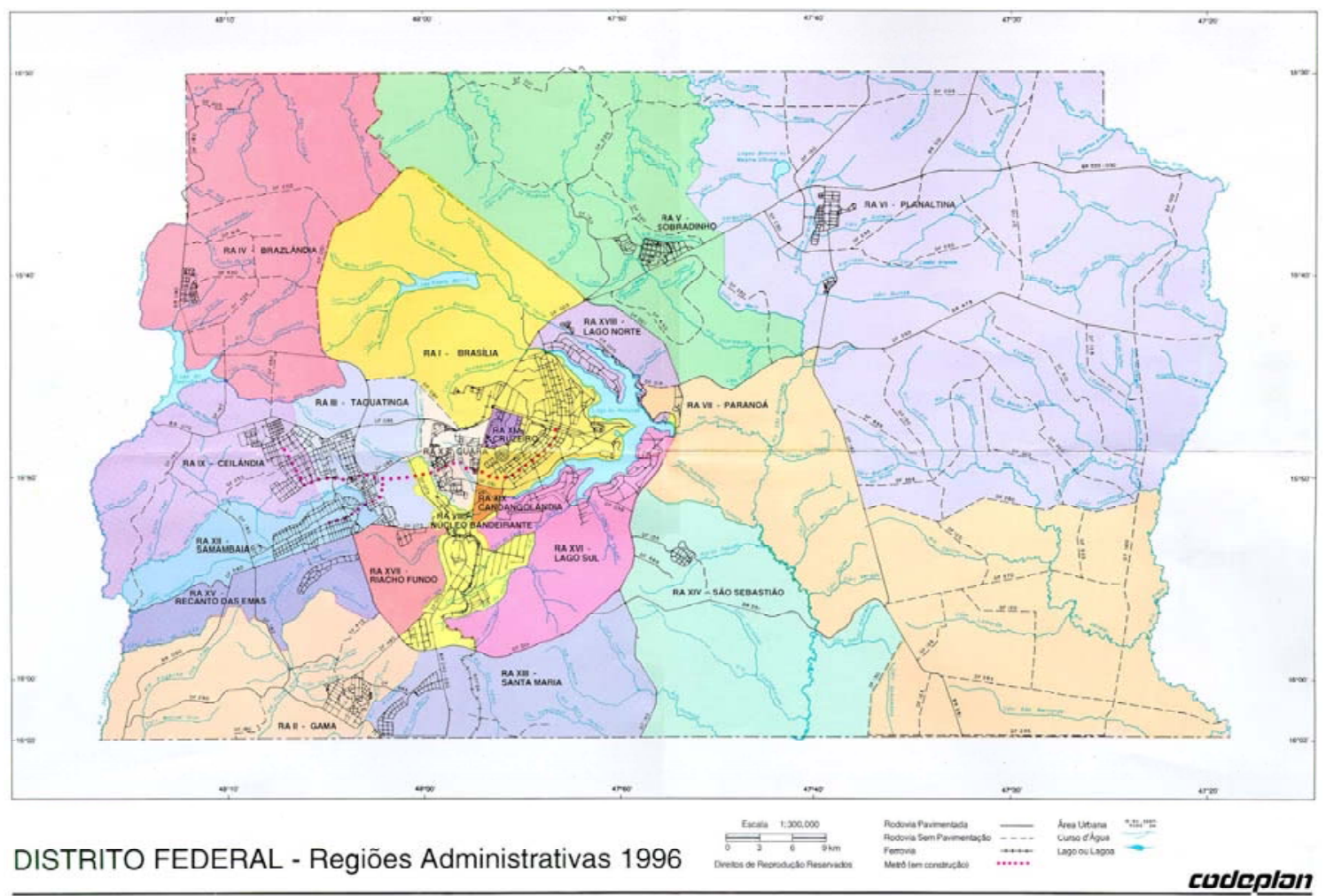

Fig. 15 Administrative regions of the federal district, including the location of Sobradinho, where the CBTKPG is located (Codeplan).

stupa, the site must be consecrated by means of the Treasure Vase, buried in the earth under the stupa, representing the eight precious substances (the mirror, the crimson pigment, the white shell, the medicine taken from the elephant's brain, the durva grass, the bilva fruit, yogurt and white mustard seeds).

The foundation or plinth-(1) symbolizes the ten virtues: three of the body (protect life, practice generosity and have an immaculate sexual conduct), four of the word (tell the truth, reconcile, speak calmly and sweetly, and have a sensible talk) and three of mind (benevolence, altruism and to have faith in the right views).

The three steps-(2) symbolize the three refuges we take (in the Buddha, the Dharma and the Sangha). The face or square base-(3) is called Lion Throne and symbolizes the superiority over the entire Universe, its four sides being the four boundless (unlimited) thoughts (boundless love, boundless compassion, boundless happiness and boundless equanimity).
Within it are placed the relics and sacred texts.

The edging-(4) and the small lotuses-(5) symbolize the six transcendent virtues (generosity, ethics, patience, energy, meditation and wisdom). The large lotuses or four sides of the base throne-(6) symbolize the four boundless ones, "the Four Unlimited". Above the base throne there are five steps forming a truncated pyramid, symbolizing the five paths (of realization of the four noble truths, of the elimination of ignorance, of clear vision, of meditation, and the path where there is nothing more to learn-passage from the tenth land into Enlightenment) towards Enlightenment, each step being, sometimes, broken up into two, thus symbolizing the ten Bodhisattva levels (bhumi) (joy supreme, immaculate, radiant, luminous, difficult to conquer, revealed, far-reaching, immovable, excellent intelligence, cloud of Dharma).

The step (7) is the base of the ten virtues (refrain from destroying life, from having an improper sexual 
conduct, from telling falsehoods, from using abusive language, from slandering, from indulging in irrelevant talk, from covetousness, from malice, from holding destructive views), and the four subsequent steps (8) symbolize, respectively, the fundamental four attentions - first step (impermanence of the body, of sensations, non-substantiality of thoughts, condition of existence-Dharmas), the four perfect efforts - second step-Sammāpadhāna (to strive to preserve existing favorable conditions, to bring about such conditions as do not yet exist, to give up existing unfavorable conditions, and not to allow such conditions to come about again), the four bases of supernormal powers-third step-Riddhipāda (meditative experience based on prayer, on thought, on perserverance and on action), and the five spiritual faculties - fourth step - Indriya (the faculties of faith, energy, attention, concentration, and knowledge).

Standing on its base (9) is the dome (11), which became a cylinder dubbed "vase" (Tibetan bumpa), widening towards the top, with a rounded upper part, typically decorated with a door (10) containing a statue of the Buddha within it, and millions of mantras, symbols of the mind of the Buddhas. The immovable base supporting the vase (9) symbolizes the five spiritual forces-Bala (faith, energy, attention, concentration, and knowledge). The vase represents the seven branches of Enlightenment-Bodhyanga

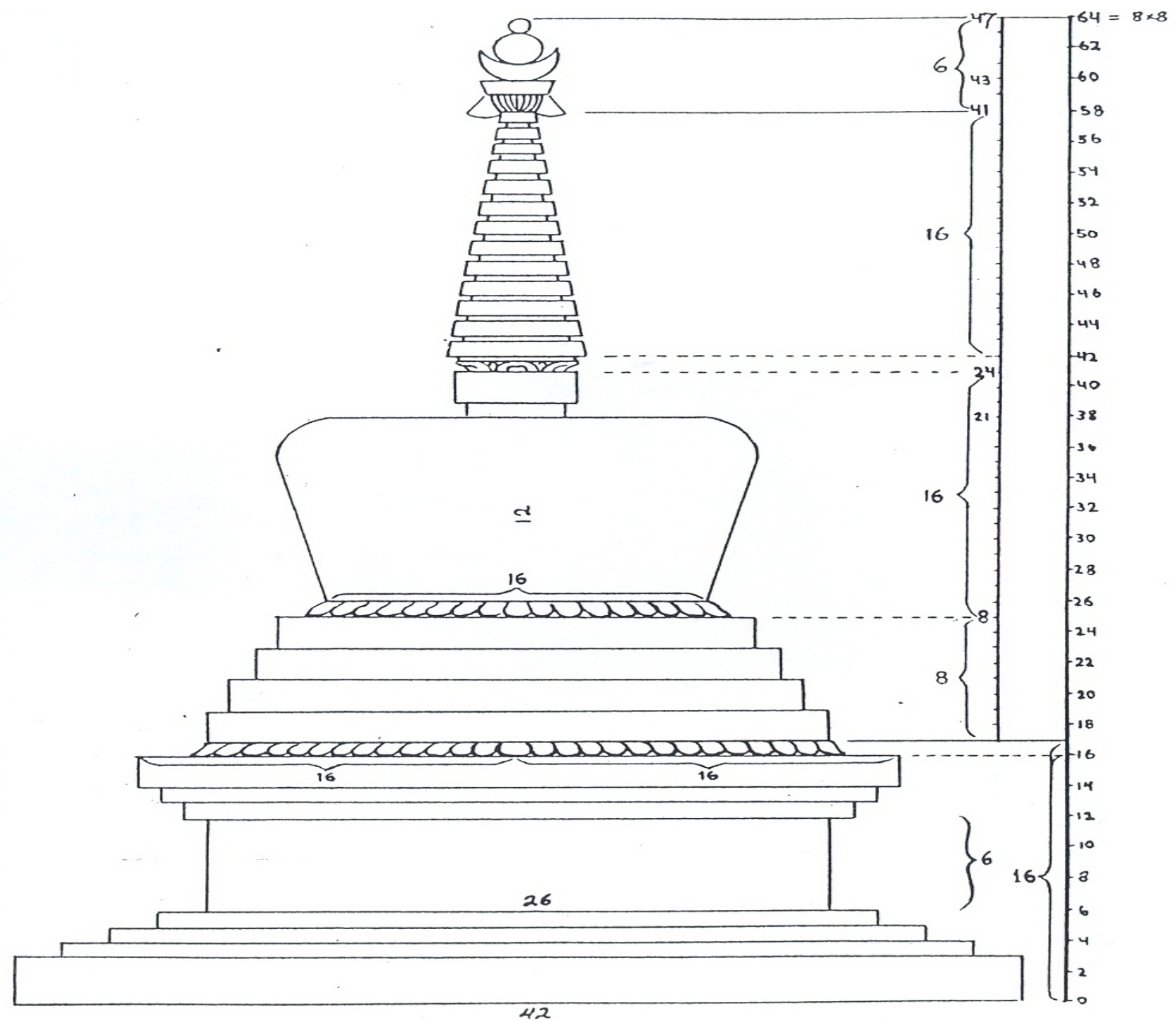

Fig. 16 Proportions of the stupa of Enlightenment [13]. 
(the full memory of past lives, the perfect knowledge of all Dharmas, diligence, ecstasy, the perfect mastery of all disciplines, concentration and equanimity).

Above it, standing over a foundation (12) and a support (13), there is a small square balustrade (14, Sanskrit harmikā), frequently marked with the eyes of the Buddha. This ensemble symbolizes the Noble Eightfold Path (perfect view, understanding, speech, action, living, effort, attention and concentration).

From the balustrade rises a spire pointing to the sky, with a base shaped like a lotus garland (15), thirteen piled concentric circles (16) and a crowning marked with a canopy (19), a cup-like structure (21), a crescent Moon (22) and a solar disk (23) capped with a volute, a spiral shell called nāda (24). The thirteen piled concentric circles (formerly parasols or umbrellas) represent the thirteen stages for reaching Buddhahood, and symbolize the ten powers and three applications of mindfulness (the power of mind, superior mind, memory, concentration, mindfulness,

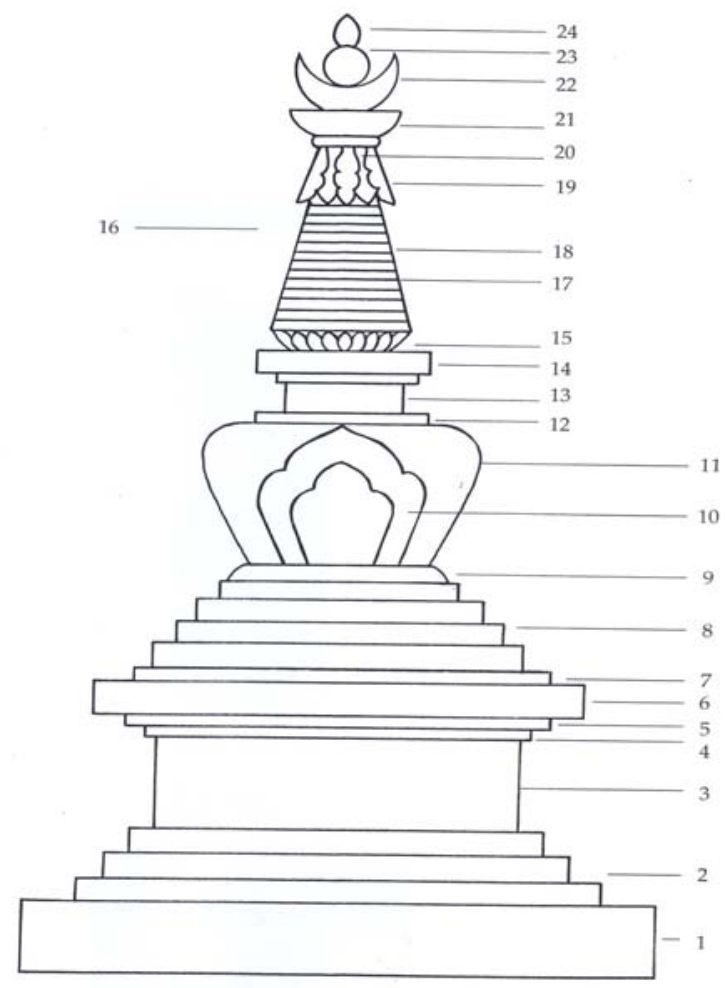

Fig. 17 The stupa of Enlightenment [14]. authority, security, desire, love and compassion, and the power of the blessing of all Buddhas, the mindfulness which makes the Buddha not feel satisfaction when the disciples listen with respect, that which makes the Buddha not feel angry when the disciples do not listen with respect, and that which makes the Buddha remain equanimous when some disciples listen with respect and others do not). Each of these rings is called father cakra (18) and the space between them (17), mother cakra.

On the central axis of the stupa is the Tree of Life, standing on the balcony, the large lotuses (6), and reaching into the thirteen wheels. It symbolizes the ten knowledges (of phenomena, of mind, of Interdependent links, of illusion, of suffering, of the origin of suffering, of the cessation of suffering, of the path leading to the cessation of suffering, of destruction, and, merged into one, of the non-appearance and of the ten transcendental knowledges).

\footnotetext{
1 -foundation

2 - stairs

3-face

4 - edging

5 - small lotuses (small border)

6-Large lotuses (balcony)

7 - the ten virtues

8 - four steps

9- seat of the vase (dome)

10 - door of the vase (dome)

11 -vase (dome)

12 - foundation of the harmika $\bar{a}^{7}$

13 - support of the harmikā

14-harmikā

15-lotus parasol

16- thirteen dharmaciakras

17 - mother cakra (space in between)

18 - father ċakra

19 - canopy

20 - symbol of compassion

21 -rain cover

22-Moon

23-Sun

24-top (nāda)
}

\footnotetext{
${ }^{7}$ Harmika is the kiosk or pavilion topping the upper terrace of a raised dwelling.
} 
The canopy (19), the lotus petals which give its form (20), symbols of compassion, and the rain cover (21) symbolize the Victorious Stage-the non-appearance and the ten transcendental knowledges. Each lotus petal (zaraizak) symbolizes the ornaments of all the Supreme Qualities. The Moon (22) symbolizes the elimination of all sufferings, the Sun (23) is the radiating of the thousand lights of compassion, and the top jewel (24) symbolizes the fulfilment of every wish.

\subsection{The Stupa of the Tibetan Buddhist Center Kagyü Pende Gyamtso of Brasilia}

The idea of building this stupa came from one of the resident Lamas at the center, Lama Sönam Sherpa, coming from the monastery of the Highly Venerable Kalu Rinpoche, in Sonada, northern India. Venerable Lama Sherab Dorje, abbot of the French monastery of Kagyü Ling, in 2003, consecrated the terrain and starts the establishment of the fundaments of construction work for a stupa to commemorate the Enlightenment of the Buddha, which was dedicated on April 23, 2006 (Figs. 18 and 19).

The development of the architectural design and of preliminary work, such as the production of tsha-tshas (small statues and stupa miniatures, made by the thousands to fill the inside of the stupa), the choice of the central Tree of Life trunk, and the collection of relics and sacred substances engaged the entire Tibetan Buddhist community and took two years. The construction process itself, another year. This stupa, although modest in architecture, remains soaked in the same religious symbolism that is typical of these buildings.

Stupas under two meters can be built in a variety of materials, but beyond this size the stupa is a building proper, and requires a foundation and structural elements according to the chosen material. Here, the material was reinforced concrete, and its structural system is shown in section (Fig. 20). Figs. 21 and 22 show the front view and dimensions of the stupa.
It stands on a concrete base $85 \mathrm{~cm}$ tall, on the lateral projection $(40 \mathrm{~cm})$ of which are placed the offerings and candles. The overall height of the stupa, including its base, is $6.51 \mathrm{~m}$ (base: $0.85 \mathrm{~m}$, trunk: 1.52 $\mathrm{m}$, the four incommensurable (steps): $0.64 \mathrm{~m}$, the vase (bumpa): $1.12 \mathrm{~m}$, harmika: $0.56 \mathrm{~m}, 13$ wheels: $1.06 \mathrm{~m}$, ensemble of the canopy, compassion symbol and rain cover: $0.22 \mathrm{~m}$, and ensemble with Moon, Sun and Jewel: $0.54 \mathrm{~m}$ ). The concrete structure ends at a height of $4.69 \mathrm{~m}$, and is continued with a metal part $1.82 \mathrm{~m}$ tall. Around the base, a hardscape surface $1.20 \mathrm{~m}$ wide serves as a circumambulation path.

Three bumpas (vases) came for the purpose from the Kalu Rinpoche monastery in Sonada, India, for the construction of the stupa, and two others were given by Lama Trinlé Drubpa, a disciple of Kalu Rinpoche.

The latter, sabum (offering bumpa for the Earth deities) and lübum (bumpa containing offerings for the deities living in water, that is, for the nāgas, marine serpents), were buried in the ground beneath

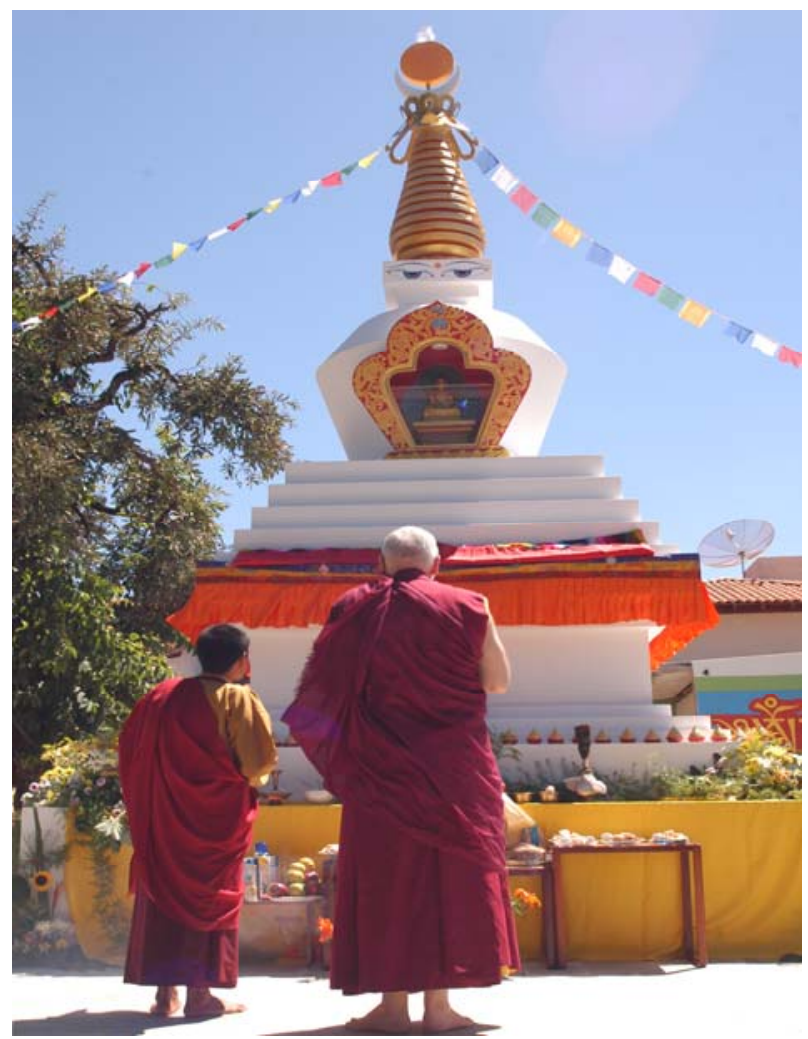

Fig. 18 Dedication of the stupa at the CTKPG (photo: Zuleika de Souza). 


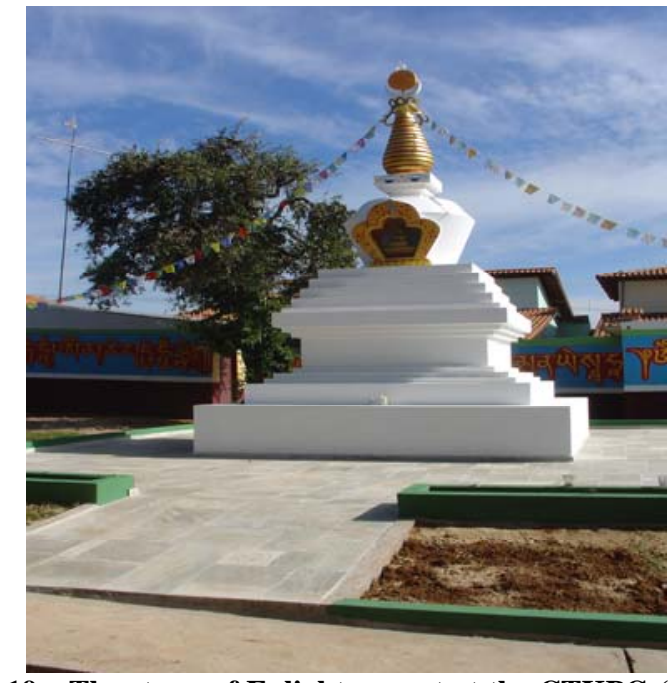

Fig. 19 The stupa of Enlightenment at the CTKPG (photo: author).

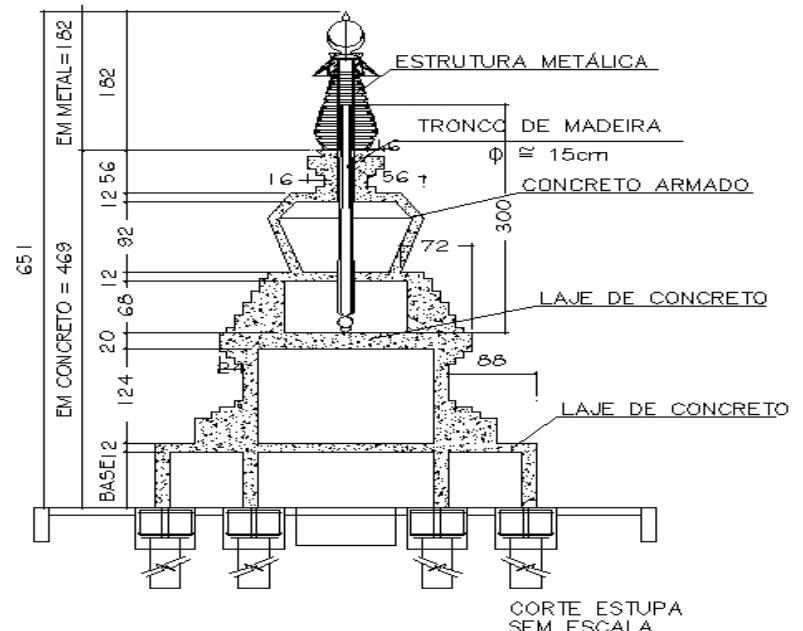

Fig. 20 Section through the stupa (Ives Yokoyama collection).

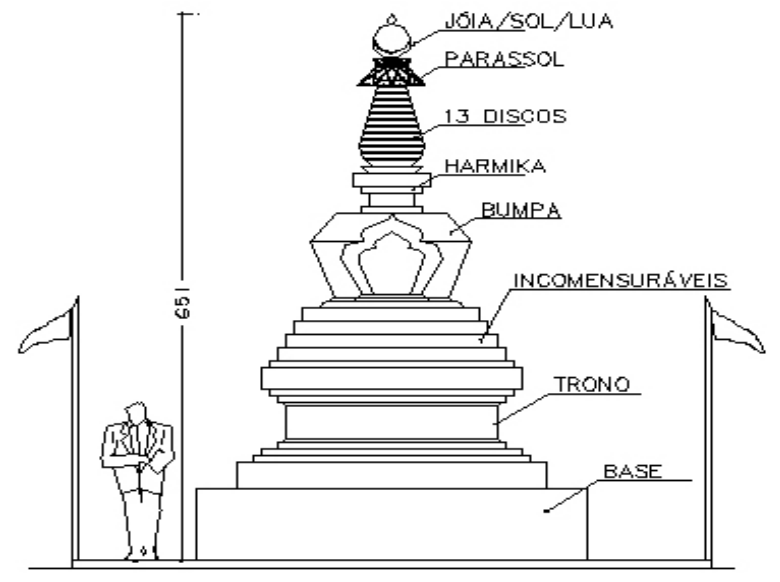

VISTA FRONTAL - ESTUPA SEM ESCALA

Fig. 21 Front view of the stupa (Yves Yokoyama collection).

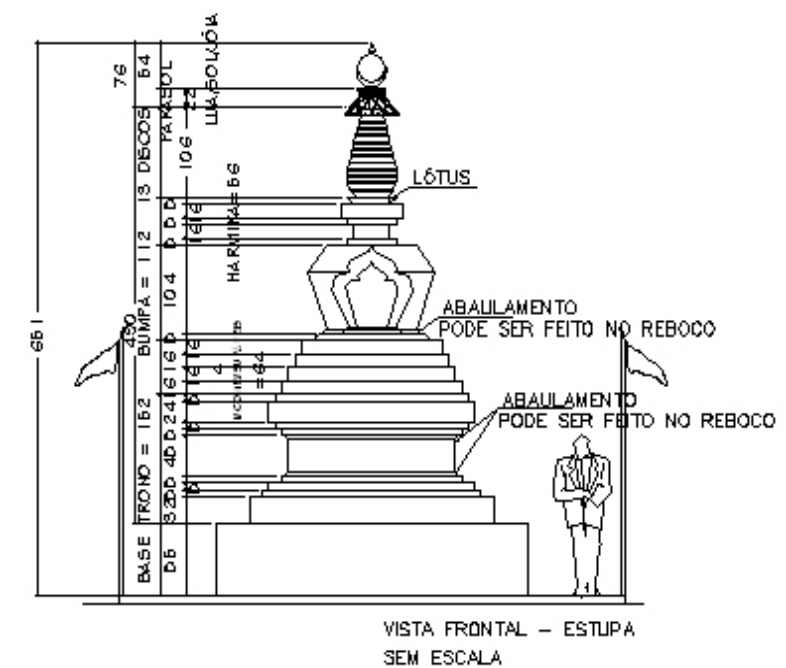

Fig. 22 Front view of the stupa-dimensions (Ives Yokoyama collection).

the stupa. The other three, called yangbum (a vase of good fortune, auspicious, containing relics inside it), together with mantras, prayers, sacred texts, spices, incenses, precious gems, relics and approximately 6,500 tshas-tshas fill the inside of the stupa up to the four steps (8), before the dome (11).

The dome, a funerary shrine, occupies the center of the monument and does not typically have outside access. At the Stupa of the Tibetan Buddhist Center of Brasilia, however, it covers a cavity, within which lies the Buddha Śākyamuni, accessible through a "door" having a richly decorated frame in dark red and golden colors. Above this, in the harmikā, are the eyes of the Buddha, representing his omniscience. A pine trunk is used as the Tree of Life. A rock crystal, symbolizing the wish-fulfilling jewel, terminates the stupa. Like all stupas, it is painted white. Prayer banners are hung from the canopy, spreading the stupa's blessings to the four directions.

\section{Conclusions}

The Cathedral is Brazilian Catholicism's major symbol, "an ecclesiastic monument all the more impressive because it retains the sacred meaning within the unity provided by the volumetric purity" [15]. The stupa is the symbol of the mind of the Buddha, an architectural expression of the spirit of 
Enlightenment and symbol of the different qualities of Buddhahood. Two architecturally different forms, which emanate force and attract the faithful, who come in a pilgrimage of offerings and prayers.

Granted the differences between religions, it is seen that both monuments have things in common, beyond the white color of their facades. There is a real integration between form and structure, volume and religious symbolism. The circular form, used in the nave of the Cathedral, is also present in the vase, the main part of the stupa. When dedicated, a stupa is seen not as a structure, but as a living and waking presence bestowing blessings. Likewise, in a Cathedral, the congregation seeks Christ's blessing, the remission of their sins in order to reach eternal life.

Although the beauty of the cathedral is in the plastic form of its structure, three angels by Ceschiatti hang from the ceiling, and together with Marianne Peretti's stained glass and the wall panels by Athos Bulcão in the baptistery, complete the decoration. The stupa, on the other hand, is lit by the eyes of the Buddha, painted on the harmikā, and by the frame of the bumpa, which shelters his image.

Another particularity is that, although both buildings have religious functions, they are not widespread forms in architecture. While the stupa forcefully recalls a centuries-old Buddhist tradition, the cathedral stems from the expressive and creative freedom of Niemeyer. So expressive it is, that the Buddhists could see in it the unfolding of a lotus flower.

\section{References}

[1] O. Niemeyer, Niemeyer, Editions Alphabet, Belmont-sur-Lausanne, Switzerland, 1977.
[2] A. Braga, F. Falcão, Guia de Urbanismo, Arquitetura e Arte de Brasília, Fundação Athos Bulcão, Brasília, Brazil, 1997.

[3] D. Underwood, Oscar Niemeyer e o modernismo de formas livres no Brasil, Cosac and Naify, São Paulo, Brazil, 2002.

[4] O. Niemeyer, Cathédrale de Brasília, in L'Architecture d'Aujourd'hui 171 (1974) 41-45.

[5] O. Niemeyer, A Catedral de Brasília, Módulo-Revista de Arquitetura e Artes Plásticas 2 (11) (1958) 4-15.

[6] C.E. Porto, Une saga technologique: les formes structurelles dans l'architecture de Brasília, in Brasília, L'épanouissement d'une capitale, Editions Picard, Paris, France, 2006, pp. 65-80.

[7] A. Vasconcelos, R.C. Junior, A Escola Brasileira do Concreto Armado, Axis Mundi Editora, São Paulo, Brazil, 2005.

[8] D.F. Pessoa, A estrutura da Catedral de Brasília: Aspectos históricos, científicos e tecnológicos de projeto, execução, intervenções e proposta de manutenção, Master's Thesis, Department of Civil and Environmental Engineering, School of Technology, University of Brasilia, 2002.

[9] M. Gerner, Architectures de 1'Himalaya, Éditions André Delcourt, Lausanne, Switzerland, 1988.

[10] P. Dorjee, Stupa and Its Technology: A Tibeto-Buddhist Perspective, Indira Gandhi National Centre for the Arts, New Delhi, Notilal Banarsidass Publishers Private Limited, Delhi, India, 1996.

[11] P. Cornu, Dictionnaire Encyclopédique du Bouddhisme, Éditions du Seuil, Paris, France, 2001.

[12] T. Sèngué, Le Temple Tibétain et son Symbolisme, Claire Lumière, France, 1998.

[13] L.A. Govinda, Psycho-cosmic Symbolism of the Buddhist Stupa, Dharma Publishing, California, USA, 1976.

[14] E. Cook, Stupa: Sacred Symbol of Enlightenment, Cristal Mirror Series, Ver. 12, Dharma Publishing, Berkeley, USA, 1997.

[15] F. Müller, Catedral de Brasília, 1958-70: Redução e Redenção, Cadernos de Arquitetura e Urbanismo 10 (11) (2003) 9-34. 